\title{
PERAN INOVASI MEMEDIASI ORIENTASI KEWIRAUSAHAAN TERHADAP KINERJA PEMASARAN BARBERSHOP DI KOTA DENPASAR
}

\author{
Made Surya Artana Putra ${ }^{1}$ \\ Putu Yudi Setiawan ${ }^{2}$ \\ ${ }^{1,2}$ Fakultas Ekonomi dan Bisnis Universitas Udayana, Bali, Indonesia \\ email: suryaartanabh@gmail.com
}

\begin{abstract}
ABSTRAK
Penelitian ini bertujuan untuk mengetahui pengaruh orientasi kewirausahaan terhadap kinerja pemasaran yang dimediasi oleh inovasi. Subjek dalam penelitian ini adalah pemilik atau pengelola Barbershop di Kota Denpasar, dengan jumlah sampel 30 orang responden. Teknik analisis yang digunakan menggunakan analisis partial least square (PLS). Hasil penelitian mengindikasikan bahwa variabel orientasi kewirausahaan berpengaruh positif dan signifikan terhadap inovasi dan kinerja pemasaran. Variabel inovasi juga berpengaruh positif dan signifikan terhadap kinerja pemasaran. Variabel inovasi juga terbukti mampu memediasi orientasi kewirausahaan terhadap kinerja pemasaran Barbershop di Kota Denpasar. Implikasi penelitian ini dapat memberikan informasi penting bagi pengusaha-pengusaha yang memiliki barbershop di Kota Denpasar untuk dapat meningkatkan kinerja pemasaran yang diharapkan meningkatkan keuntungan untuk kedepannya.
\end{abstract}

Kata Kunci: orientasi kewirausahaan, inovasi, kinerja pemasaran.

\begin{abstract}
This study aims to determine the effect of entrepreneurship orientation on marketing performance mediated by innovation. The subjects in this study were the owners or managers of Barbershop in Denpasar City, with a sample of 30 respondents. The analysis technique used uses partial least square (PLS) analysis. The results of the study indicate that the entrepreneurship orientation variable has a positive and significant effect on innovation and marketing performance. Innovation variables also have a positive and significant effect on marketing performance. The innovation variable is also proven to be able to mediate entrepreneurship orientation towards the performance of Barbershop marketing in Denpasar City. The implications of this study can provide important information for entrepreneurs who have a barbershop in Denpasar City to be able to improve marketing performance which is expected to increase profits for the future.
\end{abstract}

Keywords: entrepreneurship orientation, innovation, marketing performance 


\section{PENDAHULUAN}

Perkembangan jaman yang semakin modern membuat penampilan menjadi suatu hal yang sangat penting salah satunya tren gaya rambut. Dahulu yang gaya rambut lebih dominan ke kaum wanita, pada saat ini pria juga sudah mulai memperhatikan tren gaya rambut untuk menunjang penampilan agar terlihat lebih menarik. Fenomena tersebut membuat banyak orang melihat peluang bisnis yang cukup menjanjikan, salah satunya adalah bisnis barbershop.

Munculnya barbershop pada saat ini menjadi sebuah tren baru dari kalangan pria khususnya dalam bidang gaya rambut dan juga bisnis. Pada umumnya tempat cukur rambut hanya terlihat biasa seperti salon dan pangkas rambut yang sederhana yang masih terlihat kurang rapi ketika kita memasuki tempat panngkas rambut tersebut. Tetapi barbershop kini tampil dengan kesan yang terlihat lebih maskulin atau elegan dan bersih sehingga terlihat tertata dengan baik.

Kemunculan barbershop tak hanya di ibukota melainkan sudah berkembang hingga ke daerah-daerah. Mengusung konsep modern, cukur rambut bagi kaum pria ini pun tak hanya menawarkan potong rambut tapi juga perawatan lain yang ternyata dibutuhkan oleh kaum pria (Metrotvnews.com). Barbershop di Kota Denpasar pada Tahun 2017 yang berjumlah sebanyak 46 barbershop. Denpasr timur sebanyak 3 barbershop, Denpasar Barat sebanyak 18 Barbershop, Denpasar Selatan sebanyak 16 barbershop, dan Denpasar Utara sebanyak 10 barbershop. Menurut Agustina (2015:3) menyatakan bahwa kewirausahaan yakni seseorang yang memulai dan menciptkan suatu usaha baru dengan segala risiko dan ketidak pastian yang dihadapi dengan tujuan untuk memperoleh keuntungan serta kemampuan dalam mengidentifikasi berbagai sumberdaya yang ada untuk dapat dimanfaatkan sebagai peluang. Sedangkan menurut Susita dkk. (2017) kewirausahaan adalah kemampuan dari segi kognitif, keterampilan, dan sikap dalam menciptakan sebuah ide yang inovatif dengan penggunaan sumberdaya yang terbatas sekalipun untuk mencapai tujuan.

Pada saat ini keinginan konsumen sangatlah beragam dari penampilan gaya rambut agar dapat terlihat lebih menark di sinilah barbershop harus dapat memenuhi keinginan konsumen dan harus dapat memberikan inovasi yang terbaru agar dapat meningkatkan kinerja pemasaran dalam menghadapi persaingan yang sangat ketat.

Menurut Lianto dkk. (2016) mengungkapkan bahwa peningkatan kinerja suatu usaha didorong dengan adanya upaya inovasi yang mampu dilakukan suatu usaha. Perusahaan yang mampu melakukan inovasi dipercaya mampu meningkatkan kinerja, namun juga dipercaya dapan membantu suatu usaha dalam menghadapi persaingan yang trus berkembang (Ryiadi \& Yasa, 2016)

Kinerja merujuk pada tingkat pencapaian ataupun prestasi dari perusahaan dalam periode waktu tertentu. Adapun tujuan perusahaan terdiri dari: tetap eksis (survive), memperoleh laba (benefit), dan dapat berkembang (growth) dapat tercapai apabila perusahaan tersebut mempunyai performa yang baik (Sinarasri, 2013). Sedangkan kinerja pemasaran adalah hasil dari keseluruhan baik itu usaha, strategi, maupun kinerja yang telah dijalankan oleh suatu perusahaan (Irawan, 2015). 
Tujuan dari penelitian ini dalah sebagai berikut, 1) Untuk menjelaskan pengaruh orientasi kewirausahaan terhadap inovasi pada barbershop di Kota Denpasar. 2) Untuk menjelaskan pengaruh orientasi kewirausahaan terhadap kinerja pemasaran pada barbershop di Kota Denpasar. 3) Untuk menjelaskan pengaruh inovasi produk terhadap kinerja pemasaran pada barbershop di Kota Denpasar. 4) Untuk menjelaskan peran inovasi produk dalam memediasi pengaruh orientasi kewirausahaan terhadap kinerja pemasaran pada barbershop di Kota Denpasar.

Manfaat dari penelitian ini adalah sebagai berikut, 1) Manfaat Teoretis, penelitian ini diharapkan dapat bermanfaat bagi akademisi maupun peneliti-peneliti selanjutnya dalam memperkaya ilmu pengetahuan yang berkaitan dengan orientasi kewirausahaan, inovasi serta dampaknya terhadap kinerja pemasaran. 2) Manfaat Praktis,penelitian ini diharapkan dapat bermanfaat bagi perusahaan dalam mengembangkan inovasi serta orientasi kewirausahaan merupakan hal yang sangat penting untuk dimiliki oleh para pemilik atau pengelola Barbershop, melihat semakin meningkatnya persaingan pada lingkungan bisnis usaha Barbershop yang menuntut perusahaan untuk meningkatkan kinerja pemasarannya khususnya yang bergerak pada Barbershop.

Orientasi kewirausahaan mengacu pada kecenderungan pengambilan keputusan organisasi dalam menyokong kegiatan kewirausahaan (Fatoki, 2017). Orientasi kewirausahaan juga merupakan proses individu dalam mengejar peluang kewirausahaan berdasarkan tingkat dan sifat sumberdaya yang tersedia yang tercermin melalui sikap inovatif, berani mengambil risiko, serta bersikap proaktif Jalali et al. (2013) sedangkan menurut Poudel et al. (2012) orientasi kewirausahaan merupakan sumber daya strategis organisasi dengan potensi untuk menghasilkan keunggulan bersaing. Wirausahawan (entrepreneur) adalah seorang yang menciptakan bisnis baru dengan mengambil risiko dan ketidakpastian demi mencapai keuntungan dan pertumbuhan dengan cara mengidentifikasi peluang dan menggabungkan sumber-sumber daya yang diperlukan.

Potensi orientasi kewirausahaan dan dampaknya pada kinerja bisnis tergantung pada peran orientasi kewirausahaan sebagai penggerak atau pelopor bagi kemampuan organisasi dan inovasi. Orientasi kewirausahaan juga merupakan kunci keberhasilan organisasi dan pencapaian profitabilitas. Perusahan yang mengadopsi orientasi kewirausahaan akan memiliki kinerja yang lebih baik dibandingkan yang tidak mengadopsi (Taylor, 2013). Adapun indikator dari orientasi kewirausahaan menurut Parkman et al. (2012) adalah sebagai berikut, 1) Pencarian target pasar baru agar dapat meningkatkan kualitas. 2) Menciptakan produk baru agar memiliki nilai tambah dari konsumen. 3) Menciptakan nilai melalui usaha non produk. 4) Mencari cara agar menghindari kegagalan. 5) Berani menerima risiko jika ada kesalahan.

Robbins \& Coulter (2010) menyebutkan inovasi adalah suatu ide, gagasan, praktek atau objek/benda yang disadari dan diterima sebagai suatu hal yang baru oleh seseorang atau kelompok untuk diadopsi. Robinson (2011) mengungkapkan bahwa inovasi merupakan komersialisasi awal dari penemuan dengan menghasilkan dan menjual suatu produk, jasa, atau proses baru. Back et al. (2018), dan Babkin et al. (2015) menyatakan bahwa inovasi adalah suatu proses 
baru yang mampu diciptakan perusahaan untuk mengembangkan produk, menciptakan produk baru, ataupun melakukan pembaharuan pada proses produksi dan distribusi sehingga mampu bersaing untuk memperoleh segmen pasar baru.

Inovasi juga dapat diartikan sebagai pemikiran kreatif individu yang dapat menghasilkan ide bagi perusahaan. Ide-ide tersebut digunakan untuk membuat pemikiran baru dalam rangka membuat strategi untuk menghadapi pelanggan, pesaing, dan pasar yang telah ada. Inovasi bukan hanya tentang produk, tetapi dapat pula berupa sistem yang telah ada di perusahaan mengenai saluran pendistribusian maupun sistem pembayaran. Indikator dari inovasi menurut Cahyo \& Harjanti (2013) adalah sebagai berikut, 1) Penambahan varian agar dapat memikat konsumen. 2) Penambahan fitur varian agar konsumen dapat menentukan selera sendiri. 3) Selalu mengontrol kualitas dalam pelayanan konsumen. 4) Menggunakan produk yang berstandar kualitas.

Kinerja merujuk pada tingkat pencapaian ataupun prestasi dari perusahaan dalam periode waktu tertentu. Kinerja pemasaran adalah hasil dari keseluruhan baik itu usaha, strategi, maupun kinerja yang telah dijalankan oleh suatu perusahaan (Irawan, 2015). Adapun tujuan perusahaan terdiri dari: tetap eksis (survive), memperoleh laba (benefit), dan dapat berkembang (growth) dapat tercapai apabila perusahaan tersebut mempunyai performa yang baik (Sinarasri, 2013) sedangkan kinerja pemasaran adalah hasil dari keseluruhan baik itu usaha, strategi, maupun kinerja yang telah dijalankan oleh suatu perusahaan (Irawan, 2015). Dalam persaingan bisnis yang semakin ketat, perusahaan yang mampu meningkatkan pertumbuhan penjualan berarti memiliki kinerja yang baik (Julina \& Kusuma, 2017). Penelitian yang dilakukan Djodjobo \& Tawas (2014), Prasetya (2012), Titahena dkk. (2012), dan Sari (2013) menyebutkan beberapa indikator yang digunakan dalam mengukur variabel kinerja pemasaran adalah sebagai berikut, 1) Adanya pertumbuhan penjualan. 2) Pertumbuhan meningkatnya laba. 3) Memperluas jangkauan wilayah.

Berdasarkan penelitian sebelumnya yang dilakukan oleh Galindo \& Picazo (2013), Ryiadi \& Yasa (2016), Parkman et al. (2012), Hafeez et al. (2012), Liu et al. (2014) mendapatkan hasil bahwa pengaruh orientasi kewirausahaan berpengaruh positif dan signifikan terhadap inovasi. Berdasarkan kajian empiris dari hasil penelitian sebelumnya, dapat dibangun hipotesis adalah sebagai bertikut: $\mathrm{H}_{1}$ : Orientasi kewirausahaan berpengaruh positif dan signifikan terhadap inovasi.

Berdasarkan penelitian sebelumnya yang dilakukan oleh Titahena dkk. (2012), Mahmud \& Anomsari (2011), Djayadiningrat dkk. (2017), Hanafi \& Mahmood (2013) mendapatkan hasil bahwa pengaruh orientasi kewirausahaan berpengaruh positif dan signifikan terhadap kinerja pemasaran. Berdasarkan kajian empiris dari hasil penelitian sebelumnya, dapat dibangun hipotesis adalah sebagai bertikut:

$\mathrm{H}_{2}$ : Orientasi kewirausahaan berpengaruh positif dan signifikan terhadap kinerja pemasaran.

Berdasarkan penelitian sebelumnya yang dilakukan oleh Killa (2015), Pardi et al. (2014), Wulandari (2013), Suendro (2011), Lapian dkk. (2016), Utaminingsih (2016), Pramesti \& Giantari (2016), Ghorbani \& Abdollahi (2013) mendapatkan hasil bahwa pengaruh inovasi berpengaruh positif dan signifikan terhadap kinerja 
pemasaran. Berdasarkan kajian empiris dari hasil penelitian sebelumnya, dapat dibangun hipotesis adalah sebagai bertikut:

$\mathrm{H}_{3}$ : Inovasi berpengaruh positif dan signifikan terhadap kinerja pemasaran.

Berdasarkan penelitian sebelumnya yang dilakukan oleh Ndubisi \& Iftikhar (2012), Ryiadi \& Yasa (2016), Parkman et al. (2012), Hafeez et al. (2012) mendapatkan hasil bahwa pengaruh inovasi memediasi orientasi kewirausahaan berpengaruh positif dan signifikan terhadap kinerja pemasaran. Berdasarkan kajian empiris dari hasil penelitian sebelumnya, dapat dibangun hipotesis adalah sebagai bertikut:

$\mathrm{H}_{4}$ : Inovasi berperan secara signifikan dalam memediasi orientasi kewirausahaan terhadap kinerja pemasaran.

\section{METODE PENELITIAN}

Penelitian ini dilakukan di Kota Denpasar. Lokasi ini dipilih karena, Kota Denpasar adalah pusat trend setter dan lokasi yang paling banyak usaha yang bergerak dalam bidang barbershop. Sehingga, peneliti lebih mudah dalam mencari tanggapan responden yang akan digunakan dalam penelitian. Populasi dalam penelitian ini adalah seluruh pemilik atau pengelola barbershop di Kota Denpasar. Metode penentuan sampel yang digunakan adalah non-probability sampling dengan teknik purposive sampling. Jumlah sampel yang digunakan dalam penelitian ini ada 30 responden yang merupakan pemilik atau pengelola barbershop di Kota Denpasar. Kriteria terhadap sampel diantaranya: responden merupakan pemilik atau pengelola barbershop di Kota Denpasar, memiliki pendidikan minimal SMA/SMK/Sederajat dan Barbershop sudah beroperasi minimal satu tahun terahir.

Metode pengumpulan data dalam penelitian ini adalah dengan menggunakan kuesioner. Kuesioner diukur menggunakan Skala Likert. Kuesioner terdiri atas pernyataan terbuka dan tertutup. Pernyataan terbuka meliputi nama responden, usia responden, jenis kelamin, nama perusahaan dan alamat usaha. Pernyataan tertutup merupakan pernyataan yang telah dan diberikan pilihan jawabannya. Variabel yang digunakan dalam penelitian ini yaitu orientasi kewirausahaan sebagai variabel bebas, inovasi sebagai variabel mediasi, kinerja pemasaran sebagai variabel terikat. Pengukuran variabel menggunakan beberapa indikator diantaranya: indikator orientasi kewirausahaan adalah pencarian target pasar baru, menciptakan produk dengan nilai tambah, menciptakan nilai melalui usaha non produk, berusaha mencari cara untuk menghindari kegagalan dan berani menerima risiko kegagalan. Indikator inovasi adalah penambahan varian, penambahan fitur varian, kontrol kualitas, dan standar kualitas. Indikator kinerja pemasaran adalah pertumbuhan penjualan, pertumbuhan laba, dan jangkauan wilayah.

Teknik analisis data penelitian ini menggunakan statistik deskriptif dan statistik inferensial. Statistik deskriptif dalam penelitian ini digunakan untuk mendeskripsikan karakteristik responden dan uraian tentang skor jawaban responden di dalam kuesioner. Statistik inferensial yang dipakai dalam penelitian ini yaitu analisis Partial Least Square (PLS). Langkah-langkah analisis PLS adalah sebagai berikut:

Merancang model struktural (inner model) 
Perancangan model struktural hubungan antar variabel laten pada PLS didasarkan pada rumusan masalah atau hipotesis penelitian.

Merancang model pengukuran (outer model)

Perancangan model pengukuran dalam PLS sangat penting karena terkait dengan apakah indikator bersifat reflektif atau formatif. Model reflektif secara matematis menempatkan indikator sebagai sub-variabel yang dipengaruhi oleh variabel laten, sehingga indikator-indikator tersebut bias dikatakan dipengaruhi oleh faktor yang sama, yaitu variabel latennya. Hal ini mengakibatkan bila terjadi perubahan dari satu indikator akan berakibat pada perubahan indikator lainnya dengan arah yang sama. Dalam penelitian ini, model yang digunakan adalah model reflektif dengan mengasumsikan semua indikator seolah-olah dipengaruhi variabel laten (konstruk), oleh karena itu, yang menghendaki antar indikator saling berkorelasi satu sama lain. Model reflektif dapat dilihat pada Gambar 3.1 adalah sebagai berikut:

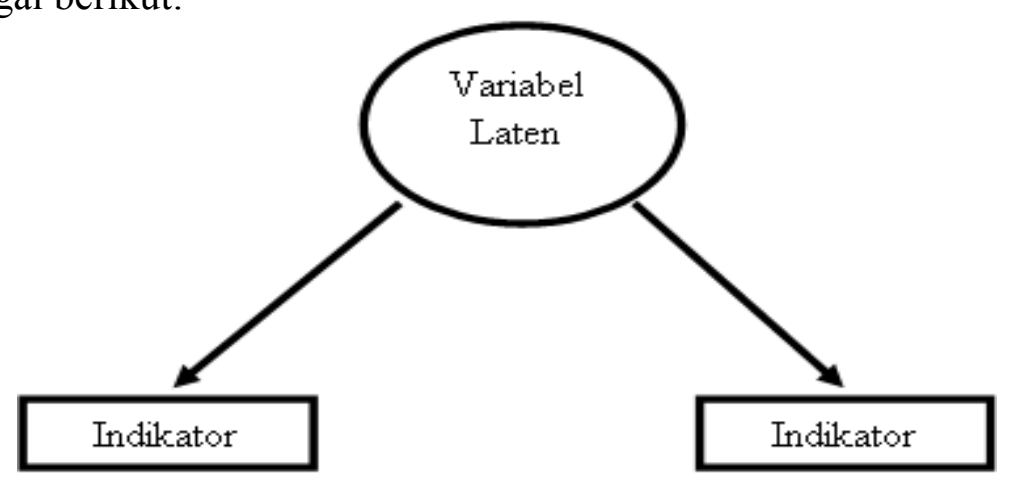

Gambar 1. Model Reflektif

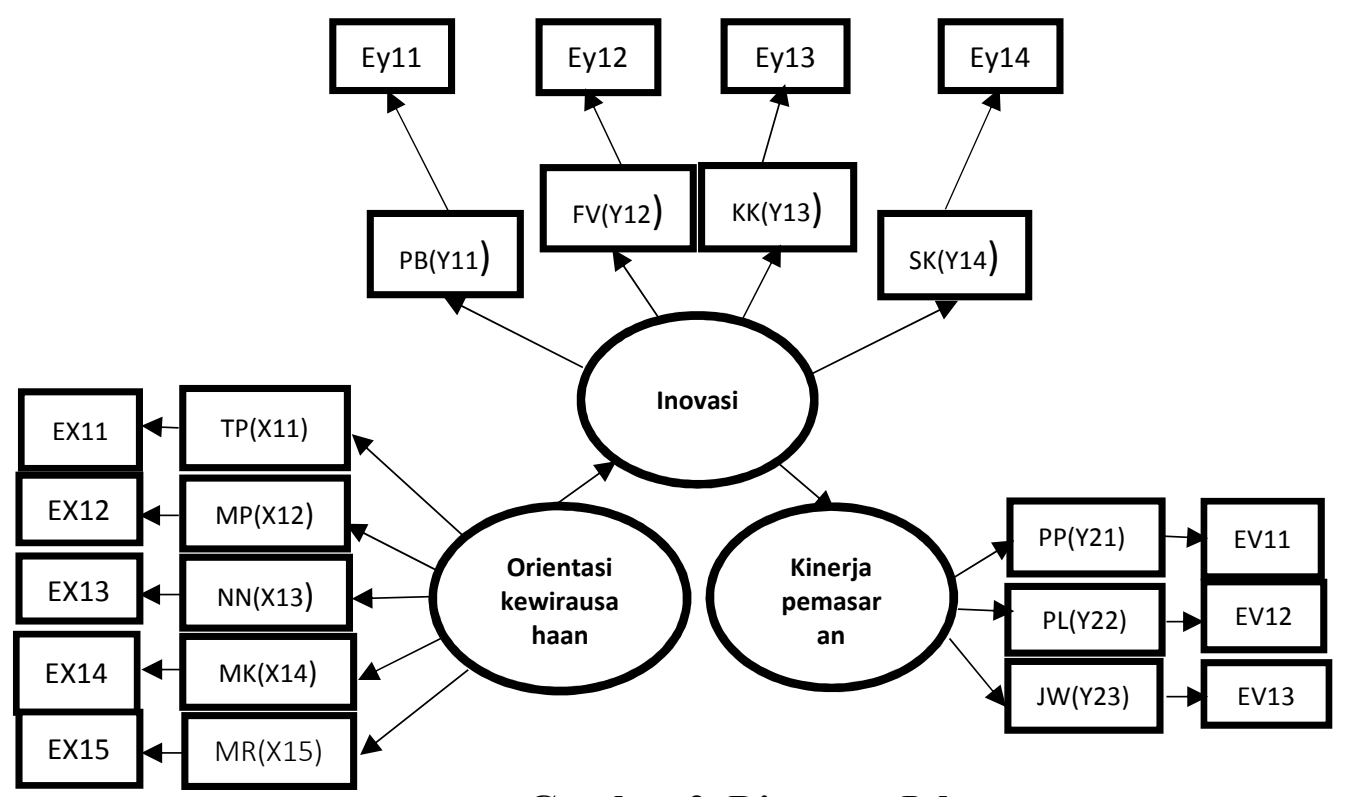

Gambar 2. Diagram Jalur 
Keterangan:

a. Indikator orientasi kewirausahaan

TP (X11) : Pencarian target pasar baru agar dapat meningkatkan kualitas.

MP (X12) : Menciptakan produk baru agar memiliki nilai tambah dari konsumen.

NN (X13) : Mendapatkan nilai dari usaha nonproduk.

MK (X14) : Mencari cara agar menghindari kegagalan.

MR (X15) : Berani menerima risiko jika ada kesalahan.

b. Indikator inovasi

PB (Y11) : Penambahan varian agar dapat memikat konsumen.

FV (Y12) : Penambahan fiture varian agar konsumen dapat menentukan selera sendiri.

KK (Y13) : Selalu mengontrol kualitas dalam pelayanan konsumen.

SK (Y14) : Mengikuti standar kualitas agar tidak terlihat aneh.

c. Kinerja pemasaran

PP (Y21) : Adanya pertumbuhan penjualan.

PL (Y22) : Pertumbuhan meningkatnya laba.

JW (Y23) : Jangkauwan wilayah.

Persamaan outer model penelitian:

Orientasi kewirausahaan $(\mathrm{X})$

$\mathrm{X} 11=\lambda \times 11 \mathrm{X}+\varepsilon \times 11$

$\mathrm{X} 12=\lambda \mathrm{x} 12 \mathrm{X}+\varepsilon \times 12$

$\mathrm{X} 13=\lambda \mathrm{x} 13 \mathrm{X}+\varepsilon \times 13$

$\mathrm{X} 14=\lambda \times 14 \mathrm{X}+\varepsilon \times 14$

$\mathrm{X} 15=\lambda \mathrm{x} 15 \mathrm{X}+\varepsilon \times 15$

Inovasi (M)

$\mathrm{Y} 11=\lambda \mathrm{y}_{11} \mathrm{M}+\varepsilon \mathrm{y}_{11}$

$\mathrm{Y} 12=\lambda \mathrm{y}_{12} \mathrm{M}+\varepsilon \mathrm{y}_{12}$

$\mathrm{Y} 13=\lambda \mathrm{y}_{13} \mathrm{M}+\varepsilon \mathrm{y}_{13}$

$\mathrm{Y} 14=\lambda \mathrm{y}_{14} \mathrm{M}+\varepsilon \mathrm{y}_{14}$

Kinerja pemasaran $(\mathrm{Y})$

$\mathrm{Y} 21=\lambda \mathrm{y}_{21} \mathrm{Y}+\varepsilon \mathrm{y}_{21}$

$\mathrm{Y} 22=\lambda \mathrm{y}_{22} \mathrm{Y}+\varepsilon \mathrm{y}_{22}$

$\mathrm{Y} 23=\lambda \mathrm{y}_{23} \mathrm{Y}+\varepsilon \mathrm{y}_{23}$

$\mathrm{Q} 2=1-(1-\mathrm{R} 12)(1-\mathrm{R} 22)$

Keterangan:

$\mathrm{R} 12=\mathrm{R}$ square kepuasan kerja

$\mathrm{R} 22=\mathrm{R}$ square komitmen organisasi 


\section{HASIL DAN PEMBAHASAN}

Responden dalam penelitian ini berjumlah 30 orang. Responden yang telah memberi tanggapan pada kuesioner penelitian ini telah memenuhi kriteria-kriteria yang telah ditetapkan dalam kriteria responden penelitian yaitu berpendidikan terakhir minimal SMA/SMK/sederajat, merupakan pemilik atau pengelola barbershop di Kota Denpasar, dan babershop yang dimilki/dikelola sudah beroprasi minimal 1 tahun terakhir. Total kuesioner yang diterima adalah 35 yang disebar dengan cara diberikan langsung kepada responden kuesioner yang memenuhi kriteria berjumlah 30 .

Adapun karakteristik dari responden disajikan pada Tabel 1.

Tabel 1.

Karakteristik Responden

\begin{tabular}{|c|c|c|c|c|}
\hline No & Variabel & Klasifikasi & $\begin{array}{l}\text { Jumlah } \\
\text { (Orang) }\end{array}$ & Persentase (\%) \\
\hline \multirow[t]{3}{*}{1} & Jenis kelamin & Laki-laki & 27 & 90 \\
\hline & & Perempuan & 3 & 10 \\
\hline & Jumlah & & 30 & 100 \\
\hline \multirow[t]{5}{*}{2} & Usia & $22-26$ & 4 & 13 \\
\hline & & $27-31$ & 6 & 20 \\
\hline & & $32-36$ & 16 & 54 \\
\hline & & $37-41$ & 4 & 13 \\
\hline & Jumlah & & 30 & 100 \\
\hline \multirow[t]{4}{*}{3} & Pendidikan terakhir & SMA/Sederajat & 5 & 16 \\
\hline & & Diploma & 2 & 7 \\
\hline & & Sarjana & 23 & 77 \\
\hline & Jumlah & & 30 & 100 \\
\hline
\end{tabular}

Sumber:Data diolah,2018

Berdasarkan Tabel 1. menunjukan bahwa sebagain besar responden yang merupakan pemilik atau pengelola barbershop di Kota Denpasar didominasi oleh responden yang berjenis kelamin laki-laki yaitu sebanyak 27 orang dan sisanya berjenis kelamin perempuani sebanyak 3 orang.

Berdasarkan variabel usia, sebagian besar responden didominasi oleh responden yang berusia 22-26 tahun yaitu sebanyak 4 orang (13\%). Responden dengan klasifikasi usia 27-31 tahun sebanyak 6 orang (20\%), responden dengan usia 32-36 tahun sebanyak 16 orang (54\%) dan responden dengan usia 37-41 tahun sebanyak 4 orang (13\%). Hal ini menunjukan bahwa mayoritas dari pemilik atau pengelola Barbershop Di Kota Denpasar adalah pada rentang usia 32-36 tahun.

Berdasarkan variabel tingkat pendidikan, sebagian besar responden didominasi oleh responden dengan pendidikan terakhir Sarjana sebanyak 23 orang (77\%). Responden dengan tingkat pendidikan terakhir SMA / sederajat yaitu sebanyak 5 orang (16\%) berada pada posisi kedua, sedangkan responden dengan pendidikan terakhir Diploma sebanyak 2 orang (7\%) menjadi respoden dengan jumlah paling sedikit. Hal ini menunjukan bahwa mayoritas dari pemilik atau pengelola Barbershop Di Kota Denpasar didominasi penduduk pada tingkat pendidikan Sarjana. 
Tabel 2.

Hasil Uji Validitas

\begin{tabular}{ccccc}
\hline No & Variabel & Indikator & $\begin{array}{c}\text { Koefisien } \\
\text { Korelasi }\end{array}$ & Keterangan \\
\hline 1 & Orientasi kewirausahaan & X.1 & 0,888 & Valid \\
& $(\mathrm{X})$ & X.2 & 0,888 & Valid \\
& & X.3 & 0,860 & Valid \\
& & X.4 & 0,869 & Valid \\
& & X.5 & 0,907 & Valid \\
2 & Inovasi (Y1) & Y.1 & 0,846 & Valid \\
& & Y.2 & 0,839 & Valid \\
& & Y.3 & 0,860 & Valid \\
& & Y.4 & 0,825 & Valid \\
3 & Kinerja Pemasaran (Y2) & Y2.1 & 0,922 & Valid \\
& & Y2.2 & 0,922 & Valid \\
& & Y2.3 & 0,904 & Valid \\
\hline
\end{tabular}

Sumber:Data diolah,2018

Hasil olah data pada Tabel 2. menunjukan bahwa nilai koefisien korelasi dari masing-masing indikator memiliki nilai lebih besar dari $0,3(\mathrm{r} \geq 0,30)$, hal ini menunjukan bahwa semua instrumen penelitian yang digunakan adalah valid.

Tabel 3.

Hasil Uji Reliabilitas

\begin{tabular}{ccccc}
\hline No & $\begin{array}{c}\text { Jumlah Item } \\
\text { Pertanyaan }\end{array}$ & Variabel & $\begin{array}{c}\text { Cronbach's } \\
\text { Alpha }\end{array}$ & Keterangan \\
\hline 1 & 5 & Orientasi & 0,928 & Reliabel \\
& & Kewirausahaan & & \\
2 & 4 & Inovasi & 0,862 & Reliabel \\
3 & 3 & Kinerja Pemasaran & 0,905 & Reliabel \\
\hline
\end{tabular}

Sumber: Data diolah, 2018

Tabel 3. menunjukan bahwa seluruh variabel dalam penelitian ini telah memenuhi syarat reliabilitas. Hal ini ditunjukan dengan nilai cronbach's alpha untuk setiap variabel lebih besar dari 0,60.

Berdasarkan Tabel 4. total rata-rata skor tanggapan responden terhadap variabel orientasi kewirausahaan adalah sebesar 4,01 yang masuk dalam kategori baik. Skor tertinggi terdapat pada pernyataan berusaha menciptakan nilai tambah terhadap konsumen melalui komunikasi yang baik terhadap konsumen, dibuktikan dengan rata-rata skor sebesar 4,27 yang dikategorikan sangat baik. Sedangkan untuk pernyataan selalu berusaha agar tidak melakukan kegagalan ataupun ada kesalahan, memperoleh rata-rata skor paling rendah sebesar 3,90. Maka dilihat dari persepsi responden, berusaha menciptakan nilai tambah terhadap konsumen melalui komunikasi yang baik terhadap konsumen menjadi pernyataan yang paling berdampak untuk variabel orientasi kewirausahaan dan pernyataan yang kurang berdampak adalah selalu berusaha agar tidak melakukan kegagalan ataupun ada kesalahan. 
Tabel 4.

Penilaian Responden pada Variabel Orientasi Kewirausahaan

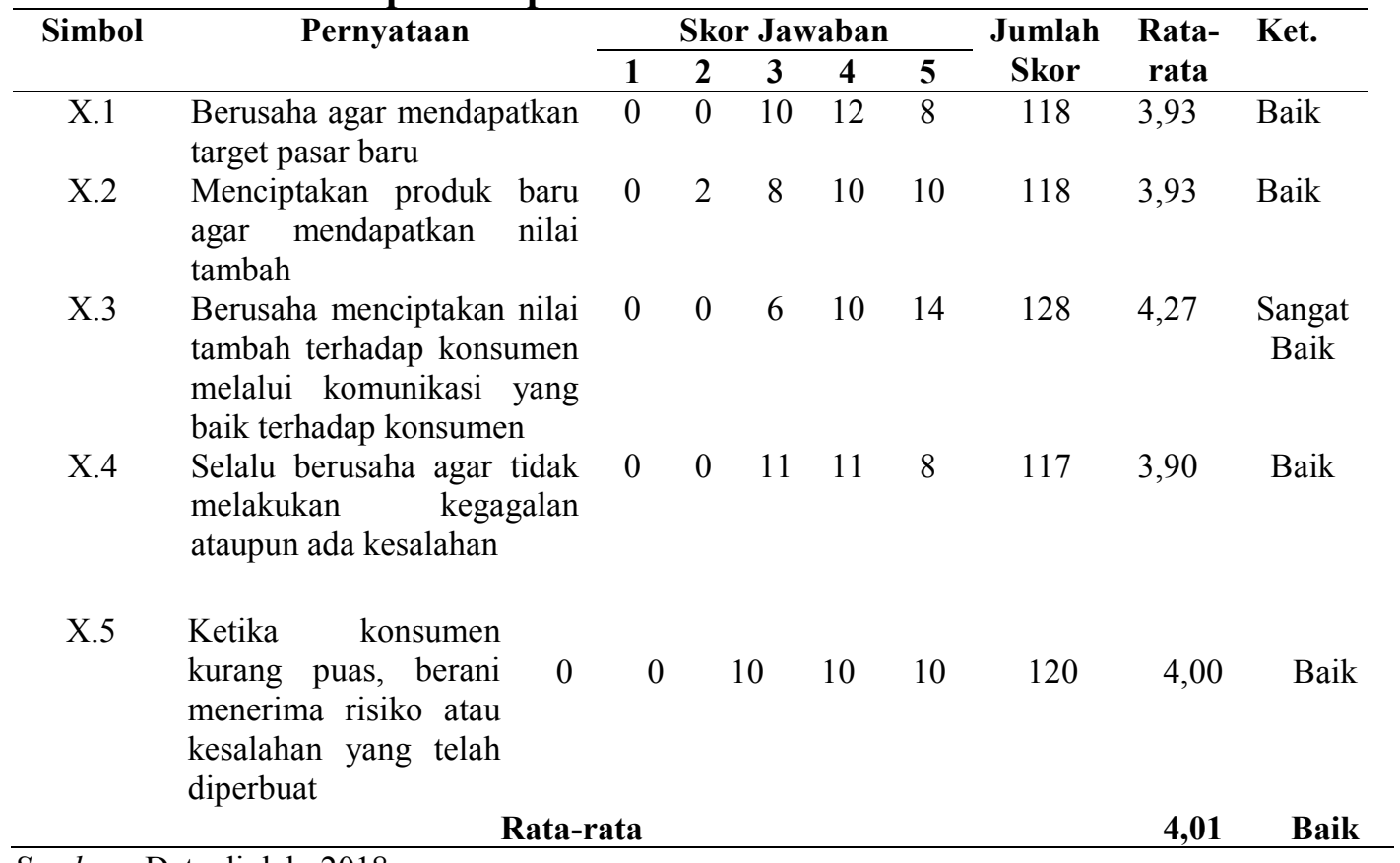

Sumber: Data diolah, 2018

Tabel 5.

Penilaian Responden Pada Variabel Inovasi

\begin{tabular}{|c|c|c|c|c|c|c|c|c|c|}
\hline \multirow[t]{2}{*}{ Simbol } & \multirow[t]{2}{*}{ Pernyataan } & \multicolumn{5}{|c|}{ Skor Jawaban } & \multirow{2}{*}{$\begin{array}{c}\text { Jumlah } \\
\text { Skor }\end{array}$} & \multirow{2}{*}{$\begin{array}{l}\text { Rata- } \\
\text { rata }\end{array}$} & \multirow[t]{2}{*}{ Ket. } \\
\hline & & 1 & 2 & 3 & 4 & 5 & & & \\
\hline Y1.1 & $\begin{array}{l}\text { Adanya beberapa } \\
\text { varian model gaya } \\
\text { rambut } \\
\text { memberikan pilihan } \\
\text { kepada konsumen }\end{array}$ & 0 & 0 & 4 & 12 & 14 & 130 & 4,33 & $\begin{array}{c}\text { Sangat } \\
\text { Baik }\end{array}$ \\
\hline Y1.2 & $\begin{array}{l}\text { Penambahan fitur } \\
\text { varian seperti pomade } \\
\text { yang digunakan agar } \\
\text { konsumen tidak } \\
\text { bosan }\end{array}$ & 0 & 0 & 10 & 12 & 8 & 118 & 3,93 & Baik \\
\hline Y1.3 & $\begin{array}{l}\text { Selalu meningkatkan } \\
\text { kualitas pelayanan } \\
\text { yang diberikan } \\
\text { kepada konsumen }\end{array}$ & 0 & 1 & 6 & 10 & 13 & 125 & 4,17 & Baik \\
\hline Y1.4 & $\begin{array}{l}\text { Tetap mengikuti } \\
\text { standar kualitas yang } \\
\text { sudah ditetapkan }\end{array}$ & 0 & 0 & 8 & 11 & 11 & 123 & 4,10 & Baik \\
\hline & Rata-rata kese & Irul & in & asi & duk & & & 3,67 & Baik \\
\hline
\end{tabular}

Berdasarkan Tabel 5. total rata-rata skor tanggapan responden terhadap variabel inovasi adalah sebesar 4,13 yang masuk dalam kategori baik. Skor tertinggi terdapat pada pernyataan adanya beberapa varian model gaya rambut agar memberikan pilihan kepada konsumen, dibuktikan dengan rata-rata skor sebesar 
4,33 yang dikategorikan sangat baik. Sedangkan untuk pernyataan penambahan fitur varian seperti pomade yang digunakan agar konsumen tidak bosan, memperoleh rata-rata skor paling rendah sebesar 3,93.

Tabel 6.

Penilaian Responden pada Variabel Kinerja Pemasaran

\begin{tabular}{|c|c|c|c|c|c|c|c|c|c|}
\hline \multirow[t]{2}{*}{ Simbol } & \multirow[t]{2}{*}{ Pernyataan } & \multicolumn{5}{|c|}{ Skor Jawaban } & \multirow{2}{*}{$\begin{array}{l}\text { Jumlah } \\
\text { Skor }\end{array}$} & \multirow{2}{*}{$\begin{array}{c}\text { Rata- } \\
\text { rata }\end{array}$} & \multirow[t]{2}{*}{ Ket. } \\
\hline & & 1 & 2 & 3 & 4 & 5 & & & \\
\hline Y2.1 & $\begin{array}{l}\text { Pertumbuhan penjualan } \\
\text { selalu meningkat setiap } \\
\text { tahunnya }\end{array}$ & 0 & 0 & 10 & 11 & 9 & 119 & 3,97 & Baik \\
\hline Y2.2 & $\begin{array}{l}\text { Pertumbuhan laba selalu } \\
\text { meningkat setiap tahunnya }\end{array}$ & 0 & 0 & 10 & 11 & 9 & 119 & 3,97 & Baik \\
\hline \multirow[t]{3}{*}{ Y2.3 } & $\begin{array}{l}\text { Membuat cabang baru agar } \\
\text { jangkauan }\end{array}$ & 0 & 0 & 12 & 11 & 7 & 115 & 3,83 & Baik \\
\hline & $\begin{array}{l}\text { pemasaran semakin luas } \\
\text { untuk kedepannya }\end{array}$ & & & & & & & & \\
\hline & Rata- & & & & & & & 3,92 & Baik \\
\hline
\end{tabular}

Sumber: Data diolah, 2018

Berdasarkan Tabel 6. total rata-rata skor tanggapan responden terhadap variabel kinerja pemasaran adalah sebesar 3,92 yang masuk dalam kategori baik. Skor tertinggi terdapat pada pernyataan pertumbuhan penjualan selalu meningkat setiap tahunnya dan pertumbuhan laba selalu menigkat setiap tahunnya, dibuktikan dengan rata-rata skor sebesar 3,97 yang dikategorikan baik. Sedangkan untuk pernyataan membuat cabang baru agar jangkauan wilayah pemasaran semakin luas untuk kedepannya, memperoleh rata-rata skor paling rendah sebesar 3,83. Maka dilihat dari persepsi responden, pertumbuhan penjualan selalu meningkat setiap tahunnya dan pertumbuhan laba selalu menigkat setiap tahunnya menjadi pernyataan yang paling tinggi skornya untuk variabel orientasi kewirausahaan dan pernyataan yang kurang skornya adalah membuat cabang baru agar jangkauan wilayah pemasaran semakin luas untuk kedepannya.

\section{Hasil Uji Partial Least Square (PLS)}

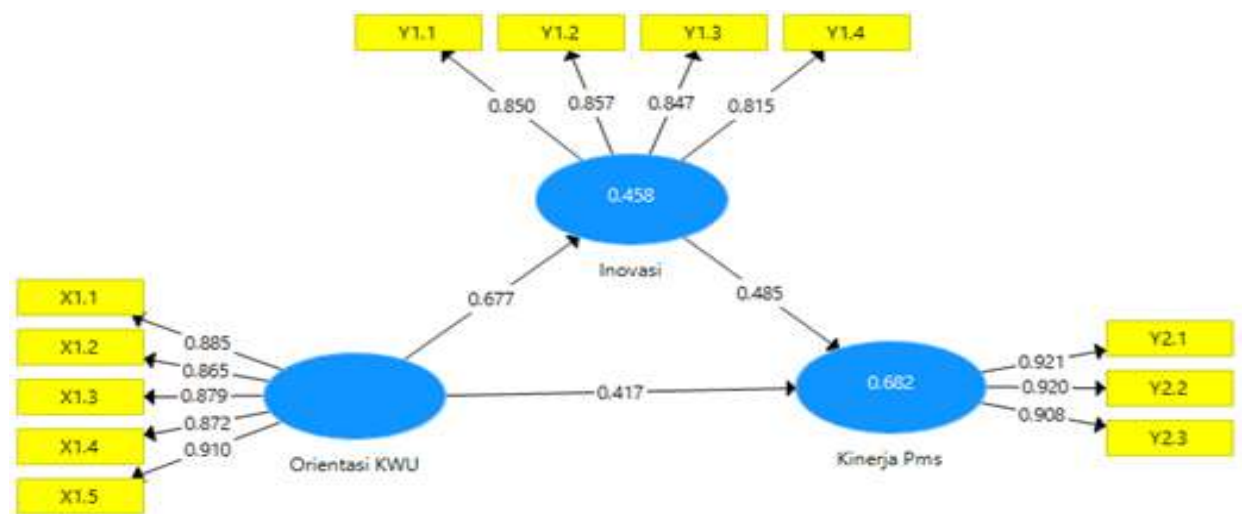

Gambar 3. Outer Model 
Uji convergent validity digunakan untuk menggambarkan korelasi konstruk dengan indikatornya. Korelasi dikatakan valid dengan nilai factur loadings berkisar diatas 0,50 . Uji convergent validity nilai factur loadings masing-masing variabel dapat dilihat pada Tabel 7 sebagai berikut :

Tabel 7.

Nilai Loadings

\begin{tabular}{ccccc}
\hline Indikator & $\begin{array}{c}\text { Orientasi } \\
\text { kewirausahaan }\end{array}$ & inovasi & $\begin{array}{c}\text { Kinerja } \\
\text { pemasaran }\end{array}$ & Keterangan \\
\hline X1.1 & 0.885 & & & Valid \\
X1.2 & 0.865 & & & Valid \\
X1.3 & 0.879 & & & Valid \\
X1.4 & 0.872 & & & Valid \\
X1.5 & 0.910 & & & Valid \\
Y1.1 & & 0.850 & & Valid \\
Y1.2 & & 0.857 & & Valid \\
Y1.3 & & 0.847 & & Valid \\
Y1.4 & 0.815 & & Valid \\
Y2.1 & & & 0.921 & Valid \\
Y2.2 & & & 0.920 & Valid \\
Y2.3 & & & 0.908 & Valid \\
\hline
\end{tabular}

Sumber: Data diolah, 2018

Berdasarkan Tabel 7. uji convergent validity menunjukkan nilai loading faktor indikator orientasi kewirausahaan, pencarian pasar target baru, menciptakan produk dengan nilai tambah, menciptakan nilai melalui usaha non produk, berusaha mencari cara untuk menghindari kegagalan, berani menerima risiko kegagalan. masing-masing memiliki nilai factur loading terhadap variabel latennya sebesar $0,885,0,865,0,879,0,872$,dan 0,910 . Nilai factur loading berkisar di atas 0,50 yang berarti seluruh indikator budaya organisasi dinyatakan valid.

Uji convergent validity menunjukkan nilai factur loading indikator inovasi seperti penambahan varian, penambahan fitur varian, kontrol kualitas, standar kualitas, pengembangan kualitas, masing-masing memiliki nilai factur loading terhadap variabel latennya sebesar $0,850,0,857,0,847$, dan 0,815 . Nilai factur loading berkisar di atas 0,50 yang berarti seluruh indikator budaya organisasi dinyatakan valid.

Uji convergent validity menunjukkan nilai factur loading indikator kinerja pemasaran seperti pertumbuhan laba, pertumbuhan penjualan, pertumbuhan pelanggan, masing-masing memiliki nilai factur loading terhadap variabel latennya sebesar 0,921, 0,920, dan 0,908Nilai factur loading berkisar di atas 0,50 yang berarti seluruh indikator budaya organisasi dinyatakan valid.

Uji discriminant validity menggambarkan korelasi antara variabel dengan nilai korelasi cross loading seluruh indikator yang digunakan dalam membentuk variabel laten dinyatakan valid apabila nilai korelasi cross loading variabel latennya yang lebih besar dibandingkan dengan korelasi terhadap variabel latent yang lain 
atau nilai AVE seluruh variabel dinyatakan valid apabila nilainya berkisar diatas 0,5. Nilai AVE masing-masing variabel dapat dilihat pada tabel 8 sebagai berikut:

Tabel 8.

Average Variance Extracted (AVE)

\begin{tabular}{lcc}
\hline \multicolumn{1}{c}{ Variabel } & $\begin{array}{c}\text { Average Variance Extracted } \\
\text { (AVE) }\end{array}$ & Keterangan \\
\hline Orientasi Kewirausahaan & 0.710 & Valid \\
inovasi & 0.840 & Valid \\
Kinerja Pemasaran & 0.778 & Valid \\
\hline
\end{tabular}

Sumber : Data diolah, 2018

Berdasarkan Tabel 8. hasil Average Variance Extracted (AVE) menunjukkan nilai AVE orientasi kewirausahaan sebesar 0,710, inovasi sebesar 0,840, dan kinerja pemasaran sebesar 0,778 yang artinya semua variabel dinyatakan valid.

Uji composite reliability seluruh variabel dinyatakan reliable apabila nilai loading-nya diatas 0,70 . Nilai composite reliability masing-masing variabel dapat dilihat pada tabel 9. sebagai berikut :

Tabel 9.

Composite Reliability

\begin{tabular}{llll}
\hline Variabel & Composite Reliability & Cronbach Alpha & Keterangan \\
\hline Orientasi kewirausahaan & 0.946 & 0,929 & Reliable \\
Inovasi & 0.907 & 0,864 & Reliable \\
Kinerja pemasaran & 0.940 & 0,905 & Reliable \\
\hline
\end{tabular}

Sumber : Data diolah, 2018

Berdasarkan Tabel 9. hasil uji composite reliability menunjukkan bahwa nilai composite reliability orientasi kewirausahaan sebesar 0,946, inovasi sebesar 0,907, dan kinerja pemasaran sebesar 0,940 yang artinya semua variabel reliable.

Evaluasi inner model dengan uji bootstrapping menghasilkan nilai koefisien determinasi $R$ square, $Q$ square, path coefficient, dan latent variable correlations. Hasil evaluasi inner model dijelaskan sebagai berikut :

Tabel 10.

Kriteria Kuat Lemahnya Pengaruh Variabel Eksogen Terhadap Variabel Endogen Berdasarkan Nilai $\mathbf{R}^{\mathbf{2}}$

\begin{tabular}{cc}
\hline $\mathbf{R}^{2}$ & Keterangan \\
\hline 0,19 & Lemah \\
0,33 & Moderat \\
0,67 & Kuat \\
\hline
\end{tabular}

Sumber: Ghozali (2011:42)

Berdasarkan hasil perhitungan yang telah dilakukan menggunakan PLS, didapatkan nilai $\mathrm{R}^{2}$ untuk pengaruh variabel eksogen terhadap variabel endogen, seperti yang disajikan dalam Tabel 10 . 
Tabel 11.

$\mathbf{R}^{2}$ Variabel Latent Endogen

\begin{tabular}{lcc}
\hline \multicolumn{1}{c}{ Variabel } & R Square & Keterangan \\
\hline Inovasi & 0.458 & Moderat \\
Kinerja Pemasaran & 0.682 & Kuat \\
\hline
\end{tabular}

Sumber : Data diolah, 2018

Berdasarkan Tabel 11. koefisien determinasi $R$ Square menunjukkan bahwa pengaruh orientasi kewirausahaan terhadap inovasi sebesar 0,458 atau 45,8 persen dikategorikan dengan pengaruh moderat, sedangkan pengaruh variabel orientasi kewirausahaan dan inovasi terhadap kinerja pemasaran sebesar 0,682 atau 68,2 persen dikategorikan kuat.

Suatu model dianggap mempunyai nilai predictive yang relevan jika nilai $Q$ square lebih dari $0(>0)$. Nilai predictive-relevance diperoleh dengan rumus :

$$
\begin{aligned}
& \mathrm{Q}^{2}=1-\left(1-\mathrm{R}_{1}^{2}\right)\left(1-\mathrm{R}_{2}^{2}\right) \ldots \ldots \\
& \mathrm{Q}^{2}=1-\left(1-0,45^{2}\right)\left(1-0,68^{2}\right) \\
& \mathrm{Q}^{2}=0,57
\end{aligned}
$$

Hasil perhitungan $Q$ Square pada penelitian ini 0,57 Hal ini berarti 57\% variabel eksogen dalam penelitian ini layak untuk menjelaskan variabel endogen yaitu komitmen organisasional.

Variabel eksogen dinyatakan signifikan pada variabel endogennya apabila hasil $\mathrm{t}$ statistic lebih besar dari t tabel 1,96 (Tingkat signifikan 5\%, DF $=40$ ). Hasil t statistic masing-masing variabel dapat dilihat pada tabel 4.12 sebagai berikut :

Tabel 12.

T Statistic

\begin{tabular}{lcccc}
\hline \multicolumn{1}{c}{ Variabel } & Koefisien & T Statistics & T Tabel & Keterangan \\
\hline Orientasi KWU. -> Inovasi & 0,677 & 7.187 & 1.96 & Signifikan \\
Orientasi KWU. -> Kinerja & 0,417 & 1.988 & 1.96 & Signifikan \\
Pms. & 0,485 & 2.218 & 1.96 & Signifikan \\
Inovasi -> Kinerja Pms. & & & &
\end{tabular}

Pada Tabel 12. nilai koefisien variabel Orientasi kewirausahan terhadap inovasi sebesar 0,677 dengan $t$ statistic sebesar 7,187 lebih besar dari pada t tabel 1,96. Hasil ini menjelaskan bahwa orientasi kewirausahaan berpengaruh positif signifikan terhadap inovasi yang berarti semakin baik atau kuat orientasi kewirausahaan maka semakin beragam inovasi yang dapat dimunculkan.

Nilai koefisien variabel Orientasi kewirausahaan terhadap kinerja pemasaran sebesar 0,417 dengan $\mathrm{t}$ statistic sebesar 1,988 lebih besar dari t tabel 1,96. Hasil ini menjelaskan bahwa orientasi kewirausahaan berpengaruh positif signifikan terhadap kinerja pemasaran yang berarti semakin baik atau kuat orientasi kewirausahaan maka akan meningkatkan kinerja pemasaran. 
Nilai koefisien variabel inovasi terhadap kinerja pemasaran sebesar 0,485 dengan t statistic sebesar 2.218 lebih besar dari t tabel 1,96. Hasil ini menjelaskan bahwa inovasi berpengaruh positif terhadap kinerja pemasaran yang artinya semakin banyak inovasi yang dapat dibuat maka kinerja pemasaran akan semakin baik.

Tabel 13.

Path Coefficients

\begin{tabular}{lccccc}
\hline Hubungan Variabel & $\begin{array}{c}\text { Pengaruh } \\
\text { langsung }\end{array}$ & $\begin{array}{c}\text { Pengaruh } \\
\text { tidak } \\
\text { langsung }\end{array}$ & $\begin{array}{c}\text { Pengaruh } \\
\text { total }\end{array}$ & $\begin{array}{c}\text { t- } \\
\text { statistics }\end{array}$ & Keterangan \\
\hline $\begin{array}{l}\text { Orientasi kewirausahaan } \\
\text { - inovasi -> kinerja } \\
\text { pemasaran }\end{array}$ & 0,417 & 0,328 & 0,745 & 2,040 & Signifikan \\
\hline
\end{tabular}

Sumber : Data diolah, 2018

Berdasarkan Tabel 13. hasil path coefficients menunjukkan bahwa inovasi mampu memediasi orientasi kewirausahaan terhadap kinerja pemasaran dengan pengaruh tidak langsung sebesar 0,328 dan t stastistik sebsar 2,040 yang lebih besar dari t tabel sebesar 1,96.

Hasil membuktikan bahwa orientasi kewirausahaan berpengaruh positif dan signifikan terhadap inovasi, hal ini sesuai dengan hipotesis satu $\left(\mathrm{H}_{1}\right)$ yang menyatakan orientasi kewirausahaan berpengaruh positif dan signifikan terhadap inovasi. Hasil penelitian ini sesuai dengan hasil penelitian sebelumnya yang diteliti oleh Ryiadi \& Yasa (2016), Parkman et al. (2012), Hafeez et al. (2012), Galindo \& Picazo (2013) yang menemukan adanya pengaruh positif pada variabel orientasi kewirausahaan terhadap inovasi. Hasil tersebut menunjukkan bahwa semakin baik orientasi kewirausahaan maka semakin membantu dalam menjalankan dan membuat inovasi.

Hasil membuktikan bahwa orientasi kewirausahaan berpengaruh positif dan signifikan terhadap kinerja pemasaran, hal ini sesuai dengan hipotesis dua $\left(\mathrm{H}_{2}\right)$ yang menyatakan orientasi kewirausahaan berpengaruh positif dan signifikan terhadap kinerja pemasaran . Hasil penelitian ini sesuai dengan hasil penelitian sebelumnya yang diteliti oleh Titahena dkk. (2012), Mahmud \& Anomsari (2011) yang menemukan adanya pengaruh positif pada variabel orientasi kewirausahaan terhadap kinerja pemasaran. Hasil tersebut sesuai dengan teori yang menyatakan bahwa orientasi kewirausahaan berfungsi sebagai membantu meningkatkan pemasaran dalam kinerja pemasaran. Hasil tersebut menunjukkan bahwa semakin baik orientasi kewirausahaan yang diterapkan organisasi maka semakin baik kinerja pemasaran barbershop tersebut .

Hasil membuktikan bahwa inovasi berpengaruh positif dan signifikan terhadap kinerja pemasaran, hal ini sesuai dengan hipotesis tiga $\left(\mathrm{H}_{3}\right)$ yang menyatakan inovasi berpengaruh positif dan signifikan terhadap kinerja pemasaran. Hasil penelitian ini sesuai dengan hasil penelitian sebelumnya yang diteliti oleh Killa (2015), Pardi et al. (2014), Wulandari (2013) yang menemukan adanya pengaruh positif pada variabel inovasi terhadap kinerja pemasaran. Hasil tersebut menunjukkan bahwa semakin banyak inovasi yang ada dalam barbershop maka kinerja pemasaran semakin baik. 
Hasil membuktikan bahwa inovasi memediasi orientasi kewirausahaan terhadap kinerja pemasaran, hal ini sesuai dengan hipotesis empat $\left(\mathrm{H}_{4}\right)$ yang menyatakan inovasi berperan secara signifikan dalam memediasi orientasi kewirausahaan terhadap kinerja pemasaran. Hasil penelitian ini sesuai dengan hasil penelitian sebelumnya yang diteliti oleh Ndubisi \& Iftikhar (2012), Ryiadi \& Yasa (2016), Parkman et al. (2012), Hafeez et al. (2012) yang menemukan bahwa inovasi mampu memediasi pengaruh orientasi kewirausahaan terhadap kinerja pemasaran. Hasil tersebut menunjukkan bahwa inovasi dapat memediasi pengaruh orientasi kewirausahaan terhadap kinerja pemasaran. Karena semakin baik inovasi maka pengaruh orientasi kewirausahaan terhadap peningkatan kinerja pemasaran semakin besar.

Penelitian ini dapat memberikan informasi penting bagi pengusahapengusaha yang memiliki barbershop di Kota Denpasar untuk dapat meningkatkan kinerja pemasaran yang diharapkan meningkatkan keuntungan untuk kedepannya. Berdasarkan hasil penelitian, orientasi kewirausahaan berpengaruh positif terhadap kinerja pemasaran, hal ini berarti perusahaan diharapkan agar selalu memperhatikan orientasi kewirausahaan agar kinerja pemasaran dalam barbershop tetap terpantau. Hasil penelitian selanjutnya yaitu orientasi kewirausahaan berpengaruh positif terhadap inovasi, hal ini berarti orientasi kewirausahaan dapat sangat membantu dalam membuat inovasi-inovasi baru agar barbershop tidak kalah dengan pesaing.

Berdasarkan hasil penelitian, inovasi berpengaruh positif terhadap kinerja pemasaran, hal ini berarti barbershop diharapkan selalu membuat inovasi baru dan mengikuti perkembangan pada massanya sehingga kinerja pemasaran dalpat berjalan dengan baik dan mendapatkan keuntungan yang diinginkan. Hasil penelitian terakhir yaitu orientasi kewirausahaan berpengaruh positif terhadap kinerja pemasaran melalui mediasi inovasi, hal ini berarti barbershop dapat meningkatkan kinerja pemasaran barbershop dengan meningkatkan orientasi kewirausahaan melalui membuat inovasi baru terhadap barbershop tersebut agar tidak kalah oleh pesaing.

\section{SIMPULAN}

Berdasarkan hasil analisis yang telah diuraikan mengenai pengaruh inovasi memediasi orientasi kewirausahaan terhadap kinerja pemasaran barbershop di kota Denpasar maka diperoleh simpulan sebagai berikut :

Orientasi Kewirausahaan berpengaruh positif terhadap Inovasi yang artinya semakin baik dan kuat orientasi kewirausahaan, maka semakin meningkatkan inovasi dalam barbershop tersebut .

Orientasi Kewirausahaan berpengaruh positif terhadap Kinerja Pemasaran yang artinya semakin baik dan kuat orientasi kewirausahaan, maka semakin meningkat kinerja pemasaaran dalam barbershop tersebut.

Inovasi berpengaruh positif terhadap Kinerja Pemasaran yang artinya semakin banyak inovasi maka semakin meningkat Kinerja Pemasaran dalam meningkatkan keuntungan. Inovasi memediasi orientasi kewirausahaan terhadap kinerja pemasaran yang artinya semakin baik inovasi dan orientasi kewirausahaan 
yang akan membantu dan meningkatkan kinerja pemasaran dalam mencari keuntungan.

Berdasarkan simpulan sebelumnya, maka beberapa saran yang dapat diberikan oleh penulis diantaranya, Penelitian ini berhasil membuktikan bahwa inovasi mampu menjadi variabel pemediasi dalam meningkatkan kinerja pemasaran barbershop , maka disarankan agar barbershop dapat terus membuat inovasi untuk meningkatkan kinerja pemasaran di barbershop tersebut. Peneliti selanjutnya disarankan untuk menggunakan variabel lain yang diduga mampu sebagai variabel pemediasi untuk lebih meningkatkan kinerja pemasaran barbershop tersebut. Barbershop di Kota Denpasar di sarankan meningkatkan aspek penambahan varian model gaya rambut agar memberikan pilihan kepada konsumen yang termasuk dalam indikator inovasi, sehingga pengaruh orientasi kewirausahaan terhadap kinerja pemasaran dapat lebih meningkat. Untuk memperoleh barbershop yang lebih di kenal olehh masyarakat, diperlukan peran pemerintah untuk peraturan perijinan seperti zona operasional barbershop di Kota Denpasar yang di masingmasing kecamatan idealnya diperbolehkan beberapa barbershop untuk mencukupi kebutuhan pelayanan terhadap konsumen di seluruh kecamatan. Kondisi ini tentunya akan berdampak positif terhadap perkembangan barbershop di Kota Denpasar, karena adanya kontrol dari pemerintah.

\section{REFERENSI}

Agustina, T. S. (2015). Kewirausahaan: Teori dan Penerapan pada Wirausaha dan UKM di Indonesia. Jakarta: Mitra Wacana Media.

Babkin, A. V., Lipatnikov, V. S., \& Muraveva, S. V. (2015). Assessing the Impact of Innovation Strategies and R\&D Costs on the Performance of IT Companies. Procedia - Social and Behavioral Sciences, 2(7), 749-758. https://doi.org/10.1016/j.sbspro.2015.10.153

Back, Y., Parboteeah, K. P., \& Nam, D. (2018). Innovation in Emerging Markets: The Role of Consulting Firms. Academy of Management Proceedings, 2(1), 159-172. https://doi.org/10.5465/ambpp.2012.15972abstract

Cahyo, R. J., \& Harjanti, D. (2013). Analisa Inovasi Produk Pada Usaha Sektor Formal Dan Informal Di Jawa Timur. Agora, 1(3), 1-10.

Djayadiningrat, A. F., Sukaatmadja, I. P. G., \& Yasa, N. N. K. (2017). Peran Inovasi Produk Memediasi Orientasi Kewirausahaan Terhadap Kinerja Pemasaran IMK Sektor Industri Makanan Kota Denpasar. E-Jurnal Manajemen Unud, 6(9), 4978-5004.

Djodjobo, C. V., \& Tawas, H. N. (2014). Pengaruh Orientasi Kewirausahaan, Inovasi Produk, dan Keunggulan Bersaing terhadap Kinerja Pemasaran Usaha Nasi Kuning. Jurnal EMBA, 2(3), 1214-1224. Retrieved from https://ejournal.unsrat.ac.id/index.php/emba/article/view/5800 
Fatoki, O. (2017). The Impact of Entrepreneurial Orientation on Access to Debt Finance and Performance of Small and Medium Enterprises in South Africa. Journal of Social Sciences, 32(2), 121-131. https://doi.org/10.1080/09718923.2012.11893058

Galindo, M. Á., \& Méndez-Picazo, M. T. (2013). Innovation, entrepreneurship and economic growth. Management Decision, 51(3), 501-514. https://doi.org/10.1108/00251741311309625

Ghorbani, H., \& Abdollahi, S. M. (2013). An Empirical Study on the Impacts of Market Orientation and Innovation on New Product Success (Case Study: Food Manufacturers in Isfahan, Iran). International Journal of Academic Research in Business and Social Sciences, 3(9), 1-13.

Ghozali, I. (2011). Aplikasi Analisis Multivariate Dengan Program IBM SPSS 19. Semarang: Universitas Diponegoro.

Hafeez, M. H., Shariff, M. N. M., \& Lazim, H. bin M. (2012). Relationship between Entrepreneurial Orientation, Firm Resources, SME Branding and Firm's Performance: Is Innovation the Missing Link? American Journal of Industrial and Business Management, 02(04), 153-159. https://doi.org/10.4236/ajibm.2012.24020

Hanafi, N., \& Mahmood, R. (2013). Entrepreneurial orientation and business performance of women-owned small and medium enterprises in Malaysia: Competitive advantage as a mediator. International Journal of Business and Social Science, 4(1), 82-90. https://doi.org/10.1177/0266242612455034

Irawan, B. R. (2015). Dampak Inovasi Produk Terhadap Kinerja Pemasaran ( Studi Kasus Pada Peluncuran Produk Baru Dalam Industri Rokok ). Agora, 3(1), 110. Retrieved from http://publication.petra.ac.id/index.php/manajemenbisnis/article/view/2750/2462

Jalali, A., Jaafar, M., \& Ramayah, T. (2013). Entrepreneurial orientation and performance: the interaction effect of customer capital. World Journal of Entrepreneurship, Management and Sustainable Development, 10(1), 48-68. https://doi.org/10.1108/wjemsd-05-2013-0030

Julina, M. M., \& Kusuma, A. A. G. A. A. (2017). Peran Inovasi Produk Memediasi Orientasi Pasar Terhadap Kinerja Pemasaran pada Fashion Retail di Kota Denpasar. E-Jurnal Manajemen Unud, 6(9), 5005-5031.

Killa, M. F. (2015). Effect of Entrepreneurial Innovativeness Orientation, Product Innovation, and Value Co-Creation on Marketing Performance. Journal of Research in Marketing, 2(3), 198. https://doi.org/10.17722/jorm.v2i3.73 
Lapian, A. A., James, M., \& Imelda, O. (2016). Pengaruh Orientasi Pasar dan Inovasi Produk Terhadap Kinerja Pemasaran pada PT. Prisma Dana Amurang. Jurnal EMBA, 6(2), 1330-1339. https://doi.org/10.15408/ess.v6i2.3775

Lianto, B., Rinawiyanti, E. D., \& Soeharsono, F. (2016). Studi Keterkaitan Kapabilitas Inovasi dan Kinerja Inovasi UKM Alas Kaki di Mojokerto. Jurnal Inovasi Dan Kewirausahaan, 4(1), 9-20. https://doi.org/10.20885/ajie.vol4.iss1.art2

Liu, H., Ding, X. hao, Guo, H., \& Luo, J. hui. (2014). How does slack affect product innovation in high-tech Chinese firms: The contingent value of entrepreneurial orientation. Asia Pacific Journal of Management, 31(1), 47-68. https://doi.org/10.1007/s10490-012-9309-5

Mahmud, \& Anomsari, A. (2011). Studi pada Usaha Kecil Menengah di Kawasan Usaha Barito Semarang. Seminar Nasional Teknologi Informasi \& Komunikasi Terapan, 1(2), 1-8.

Ndubisi, N. O., \& Iftikhar, K. (2012). Relationship between entrepreneurship, innovation and performance: Comparing small and medium-size enterprises. Journal of Research in Marketing and Entrepreneurship, 14(2), 214-236. https://doi.org/10.1108/14715201211271429

Pardi., S., Imam, S., \& Zainul, A. (2014). The Effect of Market Orientation and Entrepreneurial Orientation Toward Learning Orientation, Innovation, Competitive Advantages and Marketing Performance. European Journal of Business and Management, 6(21), 69-80.

Parkman, I. D., Holloway, S. S., \& Sebastiao, H. (2012). Creative industries: Aligning entrepreneurial orientation and innovation capacity. Journal of Research in Marketing and Entrepreneurship, 14(1), 95-114. https://doi.org/10.1108/14715201211246823

Poudel, K. P., Carter, R., \& Lonial, S. (2012). The process aspect of entrepreneurial orientation-performance relationship uncovering the mediating roles of technological capabilites, innovationa and firm growth. Frontiers of Entrepreneurship Research, 32(12), 16.

Pramesti, N. M. V., \& Giantari, I. G. A. K. (2016). Peran Orientasi Pasar Memediasi Pengaruh Orientasi Kewirausahaan terhadap Kinerja UKM Industri Kerajinan Endek. E-Jurnal Manajemen Unud, 5(9), 5754-5782.

Prasetya, A. Y. (2012). Analisis Faktor yang Mempengaruhi Keunggulan Bersaing Dalam Rangka Meningkatkan Kinerja Pemasaran. Jurnal Ilmu Manajemen Dan Akuntansi Terapan, 3(2), 7-17. 
Robbins, S. P., \& Coulter, M. (2010). Manajemen Jilid 1 (edisi 10). Jakarta: Erlangga.

Robinson, P. (2011). Manajemen Strategis: Formulasi, Implementasi, dan Pengendalian. Jakarta: Salemba Empat.

Ryiadi, N. A., \& Yasa, N. N. K. (2016). Kemampuan Inovasi Memediasi Pengaruh Orientasi Kewirausahaan terhadap Kinerja Produk IMK Sektor Industri Makanan di Kota Denpasar. E-Jurnal Apresiasi Ekonomi, 5(3), 1915-1941.

Sari, L. F. (2013). Pengaruh Motivasi Dan Lingkungan Kerja Terhadap Kinerja Pt. Augrah Raharjo Semarang. Management Analysis Journal, 2(2), 1-6.

Sinarasri, A. (2013). Analisis Pengaruh Orientasi Kewirausahaan Terhadap Strategi Bisnis Dalam Meningkatkan Kinerja Perusahaan : Studi Kasus pada Pedagang Kaki Lima Bidang Kuliner di Semarang. Universitas Muhammadiyah Semarang.

Suendro, G. (2011). Analisis Pengaruh Inovasi Produk Melalui Kinerja Pemasaran Untuk Mencapai Keunggulan Bersaing Berkelanjutan (Studi Kasus pada Industri Kecil dan Menengah Batik Pekalongan). Jurnal Sains Pemasaran Indonesia, 10(3), 317-326.

Susita, D., Mardiyati, U., \& Aminah, H. (2017). Pelatihan Kewirausahaan Bagi Pelaku Usaha Kecil Dan Binaan Koperasi Di Rumah Susun Sederhana Sewa (Rusunawa) Cipinang Besar Selatan. Jurnal Pemberdayaan Masyarakat Madani (JPMM), 1(1), 58. https://doi.org/10.21009/jpmm.001.1.05

Taylor, P. (2013). The effect of entrepreneurial orientation on the internationalization of SMEs in developing countries. African Journal of Business Management, 7(19), 1927-1937. https://doi.org/10.5897/AJBM2013.1633

Titahena, D. ., Syukur, A., \& Utomo, D. (2012). Analisis Pengaruh Orientasi Pasar, Inovasi dan Orientasi Kewirausahaan terhadap Kinerja Pemasaran Dengan Intervening Keunggulan Bersaing. Jurnal Manajemen Universitas Dian Nuswantoro, 1(1), 1-20.

Utaminingsih, A. (2016). Pengaruh Orientasi Pasar, Inovasi, Dan Kreativitas Strategi Pemasaran Terhadap Kinerja Pemasaran Pada Ukm Kerajinan Rotan Di Desa Teluk Wetan, Welahan, Jepara. Media Ekonomi Dan Manajemen, 31(2), 77-87. Retrieved from https://media.neliti.com/media/publications/149462-ID-pengaruh-orientasipasar-inovasi-dan-kre.pdf

Wulandari, A. (2013). Pengaruh Orientasi Pelanggan, Orientasi Pesaing dan Inovasi 
Made Surya Artana Putra, Peran Inovasi Memediasi...

Produk Terhadap Kinerja Pemasaran. Management Analysis Journal, 1(2), 17-21. 